\title{
Examining natural disaster literacy levels of pre-service geography teachers
}

\author{
Abdullah Türker ${ }^{1}$ and Ufuk Sözcü ${ }^{2}$ \\ ${ }^{1}$ Gazi University, Turkey (ORCID: 0000-0003-3839-2735) \\ ${ }^{2}$ Kastamonu Science High School, Turkey (ORCID: 0000-0002-6809-4774)
}

\begin{abstract}
This paper aims at determining the natural disaster literacy levels of pre-service teachers who will teach the natural geography course. The data in the present study, in which the researchers adopted a survey design conducted on 442 pre-service geography teachers (PGTs), were collected through the Natural Disasters Literacy Questionnaire. As a result, it was determined that the general natural disasters literacy of the PGTs was at a high level, but they were at a moderate level in the behavior dimension, which is one of the components of literacy. It is recommended to include subjects and practices on natural disasters in all education levels, to make all PGTs literate in natural disasters during undergraduate education, and to increase the amount of information and practices on natural disasters in the geography course with legal regulations in the dimension of curricula and textbooks.
\end{abstract}

Keywords: Natural disaster; Natural disaster literacy; Pre-service geography teacher

Article History: Submitted 2 February 2021; Revised 24 May 2021; Published online 29 June 2021

\section{Introduction}

Earthquakes, volcanic eruptions, floods, and hurricanes are all natural risks that occur as the world evolves. Natural threats are described as natural events and processes that pose a risk to human life and living environments. However, these phenomena are classified as disasters when they occur at unanticipated times or locations, or with enormous force, and their consequences hurt people and their living spaces. Disasters, according to Özey (2011) and Ergünay (2007), are the outcome of natural, human-made, or technical events that harm humans physically or socioeconomically, and have an impact on society by interrupting or stopping normal living conditions that humans are unable to manage on their own. Regardless of definitional variances, disasters are defined as incidents that result in significant losses of life and property for countries. Despite the fact that disasters create significant difficulties, losses, and deaths, the impact of a disaster such as an earthquake is dependent not only on its kind but also on the level of vulnerability of the persons and societies affected (Fothergill \& Peek, 2004; Quarantelli, 1998 as cited in Boon \& Pagliano, 2014, p. 187).

According to the United Nations Office for Disaster Risk Reduction [UNISDR-CRED] (2016), disasters are natural or man-made events that cause widespread anthropogenic, material, or

Address of Corresponding Author

Abdullah Türker, PhD, Gazi University, Gazi Education Faculty, Department of Geography Education, 06500, Ankara, Turkey.

$\triangle$ abdullahturker82@gmail.com

How to cite: Türker, A. \& Sözcü, U. (2021). Examining natural disaster literacy levels of pre-service geography teachers. Journal of Pedagogical Research, 5(2), 207-221. http://dx.doi.org/10.33902/JPR.2021270164 
environmental effects and losses, as well as severe societal malfunctions, which are attempted to be mitigated with limited resources. To be classified as a disaster, Sheehan and Hewitt (1969) claimed that there must be at least 100 persons killed, 100 people injured, or over a million dollars in damage. According to a study conducted by the Centre for Research on the Epidemiology of Disasters (CRED) (2015), satisfying two or more of the following four criteria is sufficient to classify a natural event as a disaster: (1) ten or more people dead; (2) hundred or more people are injured; (3) a state of emergency is declared and (4) there is a need for international aid. Montz, Tobin, and Hagelman (2017) noted the challenge of classifying a natural disaster as a disaster, adding that such an occurrence would have interrupted society's functioning and had significant financial consequences. The fact that similar natural events have different levels of impact on different countries makes it difficult to maintain consistency and to develop a definition of what counts as a disaster in today's world.

Turkey is subjected to dozens of natural disasters each year as a result of its geological and topographic structure, as well as its climate. Between 1900 and 2017, Turkey experienced 210 earthquakes with magnitudes greater than 6.0, according to information from the Disaster and Emergency Management Presidency (DEMP) (2018). These earthquakes claimed the lives of 86,802 individuals and badly destroyed 597,865 homes. There were 6,334 floods, 23,041 landslides and rock falls, and 1,539 avalanche incidents between 1950 and 2018. These data demonstrate the magnitude of Turkey's natural disaster risk. To lessen the dangers of catastrophes and the damage that they can inflict, a society with a high level of disaster awareness must be established.

Natural disasters have varying effects depending on a country's economic structure, investments targeted at reducing disaster damage, and the quality of disaster education provided to individuals. In today's world, where the frequency and consequences of disasters have increased, conquering natural catastrophes, minimizing the damage they create, and returning to regular routines as quickly as feasible would need obtaining disaster knowledge and applying it effectively when needed (Varol, 2007).Natural disaster education, in this sense, is critical in reducing the negative consequences of natural disasters. Natural disaster education is critical in reducing the number of natural disasters and the loss of life and property that occurs as a result of these disasters in countries all over the world. Under the heading of natural disaster literacy, such education should not only allow for the sharing of knowledge, but also for processes such as understanding and explaining natural disaster mechanisms and their formation, analyzing them, and developing behaviors that can be used to solve problems associated with such disasters.

The concept of a 'literate' person, which was equated to alphabet literacy until the 1950s, has evolved to a functional description following the UNESCO annual conference in 1978. Towards the end of the 1980s, the definitions of literacy were extended to encapsulate the demands of globalisation, recent technologies and other information processing media. It was stated in the Toronto Seminar on Literacy in Industrialised Countries in 1987 that literacy was more than just being able to read, write, and calculate (UNESCO, 2006). Literacy entails lifelong learning that allows people to achieve their goals, expand their knowledge and potential, and eventually integrate into a larger society (Knobel \& Lankshear, 2007; ALEA, 2015; Ahmed, 2011). Connor (2011) stated that the level of quantitative literacy of society needs to be improved in order to evaluate public information and figures on the natural hazards on the planet we live in and the possible problems that may arise as a result of them. In this context, it is vital to define natural disaster literacy.

Natural disaster literacy consists of dimensions such as knowledge, attitudes and behaviors concerning natural disasters. The first dimension of natural disaster literacy, which has a threedimensional structure, is the knowledge dimension. The knowledge possessed in the first dimension indicates the fundamental level. The knowledge that we encounter in our daily lives but that is not used in solving problems nor contributes to our lives is of little value. Internalising the knowledge possessed as attitudes constitutes the second dimension. The third dimension is the transformation of internalised and adopted knowledge into behaviors; this refers to advanced level 
natural disaster policies (Sözcü, 2019b). Disaster mitigation can be defined as measures taken in advance to reduce the impact of a disaster and it includes structural measures such as safer building construction and non-structural measures such as education, training, and technology transfer. Disaster mitigation refers to preemptive measures taken before an emergency or disaster happens to remove or lessen the impacts and risks of hazards. It will be useful to use educational activities to support disaster reduction efforts, disaster preparedness, and the creation of a society with a high degree of disaster literacy (Sampurno, Sari, \& Wijaya, 2015).

The disaster literacy paradigm, according to Brown et al. (2014), incorporates four levels of literacy that enable people to exert greater control and personal accountability, as well as enhanced knowledge of elements that impact their efforts, such as the context in which they are working. This four levels disaster literacy model is shown Figure 1.

Figure 1

Four levels disaster literacy model (Brown et al., 2015, p. 270)

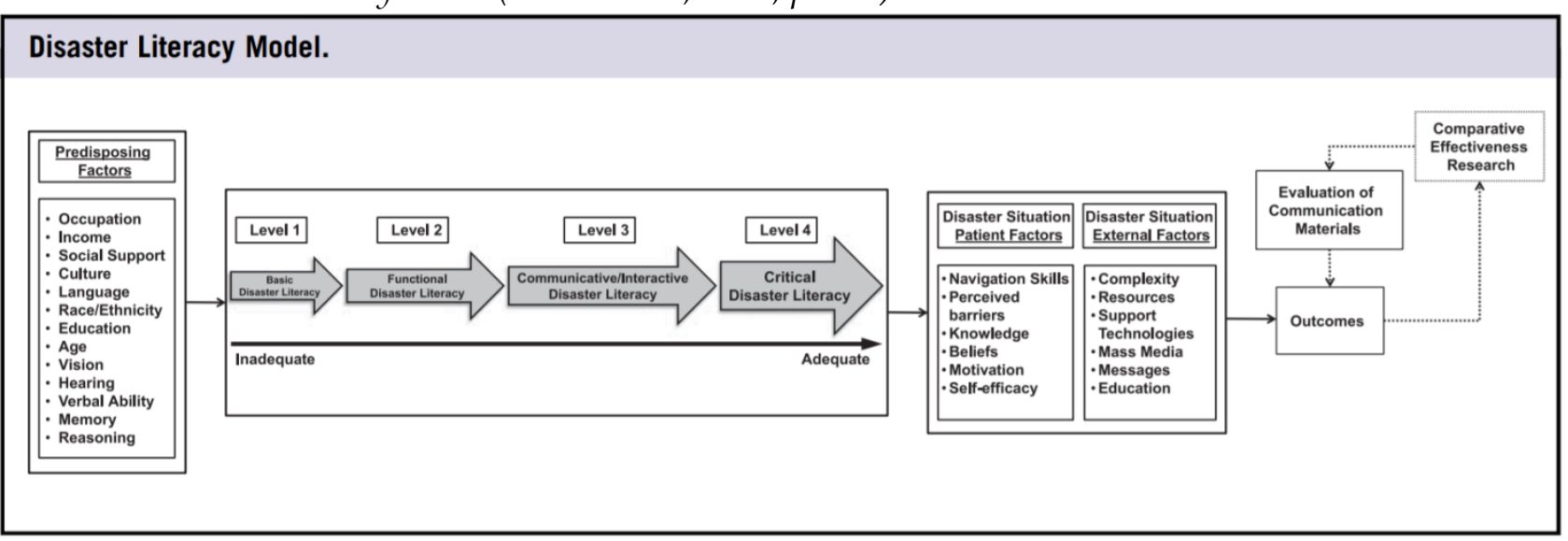

Parents, without a doubt, bear the primary responsibility for instilling natural disaster literacy in their children. Beginning in preschool and continuing through all stages of education, teachers play an important part in this process. In their work, Zhu and Zhung (2017) emphasized that school-based disaster education is very crucial in reducing the damages of natural disasters after the Wenchuan earthquake. Teachers must instill the required knowledge, awareness, and skills about natural disasters in students, especially during their undergraduate studies, in order for them to achieve natural disaster literacy. Natural disasters are an interdisciplinary subject of research since they represent a shared area of interest for both natural and social sciences. The scope and results of classroom education in science and social sciences sources during primary and secondary school are linked to natural disasters, according to the Ministry of Education's curriculum. In high school, the geography course is the best place for pupils to learn about natural disasters. However, according to the study of Sözcü (2019a) there are issues with natural disaster literacy because the outcomes related to natural disasters cannot go beyond theoretical knowledge and students and parents adopt an approach that focuses on test-oriented learning for exams, such as high school and university admission tests.

In their research, Cvetkovic and Stanisic (2015) looked into the effects of environmental and demographic factors on students' perceptions of natural disasters, whereas Chung and Yen (2016) looked into disaster prevention literacy and disaster prevention education for school administrators and teachers. One of the most significant outcomes of their research was the development of a scale with knowledge, attitude, and skill dimensions to determine disaster prevention literacy improvements in order to reduce the damage caused by earthquakes during school days, which was then applied to school administration and students. In another study, Goddard (2017) examined the disaster preparedness of undergraduate students regarding the risk perceptions, beliefs, and self-efficacy. Brown et al. (2015) presented a four-level approach for students with disabilities whose natural catastrophes relationship was deemed the least useable 
and most fragile in their work. Rahim and $\mathrm{Wu}$ (2015) examined whether disaster prevention framework played a vital role in Taiwan's disaster education and concluded that the framework for fostering disaster prevention literacy is effective and might be used as a model in earthquakeprone nations where people's earthquake preparedness is lacking. In a recent study, Kamil et al. (2020) examined the effects of geographic literacy and the use of geographic teaching materials in the development of disaster information for high school students. Their results demonstrated that students' knowledge and understanding of disaster-related information increased by $91.6 \%$ as a result of geographic literacy provided in student learning.

When the conducted research summarized above were analyzed, it was observed that many literacy dimensions such as disaster preventive literacy, disaster management literacy, and disaster mitigation literacy were also focused on detecting student, teacher, and community attitudes of disasters. The prevention, intervention, and improvement stages of modern disaster management were not the focus of this study. In the event of a natural disaster, a comprehensive literacy study was prepared. In this sense, geography teachers should be given extra attention since they are deeply interested in matters of life, and their vulnerability to societal difficulties is higher than that of other disciplines' teachers. As a result, research to identify pre-service geography teachers' (PGTs) natural disaster literacy levels, analyze them in terms of numerous characteristics, and make recommendations for essential arrangements and improvements are clearly needed.

\subsection{The Aim}

The goal of this study was to establish the natural disaster literacy levels of PGTs, as well as the effects of various variables on the components of natural disaster literacy (e.g., knowledge, affective dispositions, behavior). Studies to raise natural disaster literacy levels in Turkey and around the world will help to reduce the economic damage caused by natural disasters, including economic damage. This study hopes to contribute to research on natural disaster literacy being conducted in other countries.

\section{Method}

\subsection{Research Design}

The survey method was utilized in this study. A survey is a research strategy used to reveal the thoughts and attitudes of participants at a certain time, under certain conditions, so that they can generalize on the subject studied in less time. This method is also known as gathering little amounts of data from a large number of people using standardized forms (Robson, 2002). Survey studies, according to Büyüköztürk et al. (2014), aim to explain the features of big masses and provide an opportunity to answer questions like what, where, how often, to what extent, and how.

\subsection{Participants}

The study's participants were pre-service teachers enrolled in university geography departments. The sample group comprised of 442 geography students (1st through 4th grades) from four Turkish universities. Criterion sampling, a non-random deliberate sampling strategy, was used to obtain the study's sample. In order to ensure quality assurance efforts, criterion sampling (Patton, 2002) was employed, and participants from universities across Turkey (Black Sea, Mediterranean, Eastern, and Central Anatolia) were included in the study. Table 1 shows demographic information on the university students who took part in this study.

\subsection{Instrument}

The study used the Natural Disaster Literacy Questionnaire, which was created by Sözcü (2019) and consists of four parts. The introduction part contains 13 questions that comprise variables that are thought to affect PGTs' natural disaster literacy. The first part consists of the 25-item Natural Disaster Affective Dispositions Scale, Affective Dispositions Scale, 
Table 1

Demographic information regarding university students

\begin{tabular}{lcc}
\hline Gender & $N$ & $\%$ \\
\hline Female & 271 & 61.3 \\
\hline Male & 171 & 38.7 \\
\hline Grade Level & & \\
\hline Grade 1 & 114 & 25.8 \\
\hline Grade 2 & 123 & 27.8 \\
\hline Grade 3 & 89 & 20.1 \\
\hline Grade 4 & 116 & 26.2 \\
\hline University & & 30 \\
\hline Kastamonu University & 133 & 10.4 \\
\hline Gazi University & 46 & 27.6 \\
\hline Ardahan University & 122 & 31.9 \\
\hline Akdeniz University & 141 & 100
\end{tabular}

the other component of natural literacy, consists of 25 items, 16 of which are positively worded while 9 are negatively worded. The Affective Dispositions Scale consists of three sub-dimensions, namely, susceptibility, awareness and individual and societal readiness. In the susceptibility dimension, measures, ideas, and approaches to natural disasters; in the awareness section, what needs to be done for natural disasters, and in the individual and social preparation dimension, items about attitudes on the basis of individual and societal are included. The Cronbach's alpha reliability coefficient of the Affective Dispositions Scale was calculated as .85. The second part consists of the 23-item Natural Disaster Behavior Scale. Sixteen items in the behavior scale are positively worded, 7 are negatively worded. The behavior scale consists of three sub-dimensions, namely, geographic inquiry, personal protection measures, and physical and ideological approach. In the realm of geographic inquiry, there are questions about disaster creation, dispersion, and environmental-human interaction. In the personal protection dimension, there are items for measures to be taken against the types of natural disasters. In the physical and ideological approach dimension, there are items about the personal approach before, during and after natural disasters. The Cronbach's alpha reliability coefficient of the behavior scale was calculated as 0.81 .

The final part consists of a natural disasters knowledge test consisting of 24 questions in different categories and levels of knowledge prepared considering to Bloom's taxonomy. The Kuder-Richardson-20 (KR-20) reliability coefficient of the questionnaire was calculated as 0.81 . The Cronbach's alpha reliability coefficient of the behavior scale was calculated to be 0.81 , the Affective Dispositions Scale as .85 and the overall reliability of the scale was .86. In general, the items constituting the scale were considered to be reliable and as having very good items.

The data was provided with the cooperation of lecturers from the universities listed in Table 1 during October and November 2019. The surveys were delivered in a file to the pre-service instructors, together with the relevant explanations. The researchers collected the data on a voluntary basis.

\subsection{Data Analysis}

SPSS 20 was used to analyze the data acquired in this study. The missing data were initially filled in by inserting mean values. The dataset's 15 outlier values were eliminated from the analysis. The 15 outlier values detected in the dataset were removed from the analysis. The main criterion for the extraction of these data is that there are too many items left empty to affect the reliability of the survey. Finally, 442 responses were checked for whether they met the requirements of normality to determine the statistical method to be used for data analysis (i.e. parametric and non-parametric). Normality was tested separately for all scales and each of the variables. The Kolmogorov-Smirnov 
test was run, and the skewness and kurtosis coefficients were checked to test normality $(-0.78$, +0.63 ). After establishing that the dataset was normally distributed, which was the first requirement, an independent samples t-test was conducted to find the difference between the mean scores of two independent samples (i.e. in cases where variances are equal/ not equal), and one-way analysis of variance (ANOVA) was conducted in cases where there were three or more independent variables. As a result of the analysis, the information about which test was used is given in the related tables in the findings section.

Determining natural disaster literacy levels, the method developed by McBeth et al. (2008) was used. Natural disaster literacy was divided into three levels (i.e. low, moderate and high). The total score that could be achieved in each scale was 60 , and 180 for the whole questionnaire. Details regarding this method are provided in Table 2.

Table 2

Multiplier Values Used in Determining PGTs' Disaster Literacy Levels and the Maximum Scores for each Sub-scale

\begin{tabular}{|c|c|c|c|c|c|}
\hline $\begin{array}{l}\text { Components of } \\
\text { Natural Disaster } \\
\text { Literacy }\end{array}$ & Sub-dimension & $\begin{array}{l}\text { Number of } \\
\text { Questions }\end{array}$ & $\begin{array}{l}\text { Score } \\
\text { Interval }\end{array}$ & Multiplier & Maximum Score \\
\hline \multirow{3}{*}{ Behavior } & Geographic inquiry & 10 & $10-50$ & 0.52 & 26 \\
\hline & $\begin{array}{ll}\text { Personal } & \text { Protection } \\
\text { Measure } & \\
\end{array}$ & 6 & $6-30$ & 0.53 & 16 \\
\hline & $\begin{array}{l}\text { Physical and Ideological } \\
\text { Attitudes }\end{array}$ & 7 & $7-35$ & 0.51 & $\begin{array}{c}18 \\
\text { Total: } 60\end{array}$ \\
\hline \multirow{3}{*}{$\begin{array}{l}\text { Affective } \\
\text { Disposition }\end{array}$} & Susceptibility & 15 & $15-75$ & 0.48 & 36 \\
\hline & Awareness & 7 & $7-35$ & 0.48 & 17 \\
\hline & $\begin{array}{l}\text { Individual and Societal } \\
\text { Readiness }\end{array}$ & 3 & 3-15 & 0.46 & $\begin{array}{c}7 \\
\text { Total: } 60\end{array}$ \\
\hline \multirow{5}{*}{ Knowledge } & $\begin{array}{l}\text { Distribution of natural } \\
\text { disasters }\end{array}$ & 3 & $0-3$ & 2.5 & 7.5 \\
\hline & $\begin{array}{l}\text { Natural disaster } \\
\text { management and its } \\
\text { general qualities }\end{array}$ & 7 & $0-7$ & 2.5 & 17.5 \\
\hline & $\begin{array}{l}\text { Climatological- } \\
\text { Meteorological disasters } \\
\text { and their effects on human } \\
\text { beings }\end{array}$ & 8 & $0-8$ & 2.5 & 20 \\
\hline & Geological disasters and & & & & 15 \\
\hline & $\begin{array}{l}\text { their effects on human } \\
\text { beings }\end{array}$ & 6 & $0-6$ & 2.5 & Total: 60 \\
\hline Total & & 72 & $48-264$ & & 180 \\
\hline
\end{tabular}

According to McBeth et al. (2008), a maximum of 60 points can be acquired from each part, for a total of 180 points, using the scale they developed. The natural disasters knowledge test, for example, has 24 questions. The total correct number must be multiplied by a factor of 2.5 in order for a participant to receive 60 points while answering all questions properly. Likewise, in order for a participant to get a full score from the behavioral scale, the total number of accuracy must be multiplied by 0.52 and 0.48 on the affective disposition scale. When these values are taken into consideration, the 0-20 point range represents a low level, the 21-40 point range represents a moderate level, and the 41-60 point range represents a high level. In the behavioral and affective tendencies scale, scores between 12 and 27 indicate a low level, scores between 28 and 44 indicate a moderate level, and scores between 45 and 60 indicate a high level. In sum, the ranges 24-75 
represent low-level natural disaster literacy, 76-128 intermediate-level natural disaster literacy, and 129-160 high-level natural disaster literacy.

\section{Results}

This section summarizes the results in relation to the research problem and its sub-dimensions. For each sub-goal, the outcomes are explained and displayed as tables.

\subsection{Pre-service Geography Teachers' Natural Disaster Literacy Levels}

The obtained results regarding natural disaster literacy levels of the participants are presented in Table 3.

Table 3

Determining PGTs' Natural Disaster Literacy Levels

\begin{tabular}{|c|c|c|c|c|c|c|c|}
\hline & Sub-dimension & & Low & Moderate & High & $\bar{X}$ & $S D$ \\
\hline \multirow{15}{*}{ 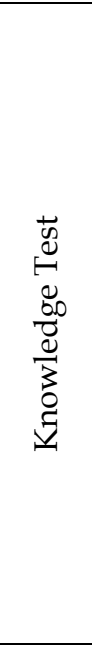 } & \multirow{3}{*}{$\begin{array}{l}\text { Distribution of natural } \\
\text { disasters }\end{array}$} & Range & $0-2.5$ & $2.6-5$ & $5.1-7.5$ & \multirow{3}{*}{5.10} & \multirow{3}{*}{0.87} \\
\hline & & $\mathrm{n}$ & 107 & 181 & 154 & & \\
\hline & & $\%$ & 24.2 & 41 & 34.8 & & \\
\hline & \multirow{3}{*}{$\begin{array}{l}\text { Natural disaster management } \\
\text { and its general qualities }\end{array}$} & Range & $0-6$ & $7-11$ & $12-17.5$ & \multirow{3}{*}{14.74} & \multirow{3}{*}{1.29} \\
\hline & & $\mathrm{n}$ & 14 & 47 & 381 & & \\
\hline & & $\%$ & 3.2 & 10.6 & 80.8 & & \\
\hline & \multirow{3}{*}{$\begin{array}{l}\text { Climatological-Meteorological } \\
\text { disasters and their effects on } \\
\text { human beings }\end{array}$} & Range & $0-7$ & $8-14$ & $15-20$ & \multirow{3}{*}{12.75} & \multirow{3}{*}{1.13} \\
\hline & & $\mathrm{n}$ & 37 & 206 & 199 & & \\
\hline & & $\%$ & 8.4 & 46.6 & 45 & & \\
\hline & \multirow{3}{*}{$\begin{array}{l}\text { Geological disasters and their } \\
\text { effects on human beings }\end{array}$} & Range & $0-5$ & $6-10$ & $11-15$ & \multirow{3}{*}{10.28} & \multirow{3}{*}{1.51} \\
\hline & & $\mathrm{n}$ & 69 & 172 & 201 & & \\
\hline & & $\%$ & 15.6 & 39 & 45.4 & & \\
\hline & \multirow{3}{*}{ Grand Total } & Range & $0-20$ & $21-40$ & $41-60$ & \multirow{3}{*}{42.90} & \multirow{3}{*}{4.8} \\
\hline & & $\mathrm{n}$ & 24 & 143 & 275 & & \\
\hline & & $\%$ & 5.4 & 32.3 & 62.3 & & \\
\hline \multirow{12}{*}{  } & \multirow{3}{*}{ Susceptibility } & Range & $7-16$ & $17-26$ & $27-36$ & \multirow{3}{*}{30.46} & \multirow{3}{*}{9.18} \\
\hline & & $\mathrm{n}$ & 3 & 94 & 345 & & \\
\hline & & $\%$ & 0.7 & 21.3 & 78 & & \\
\hline & \multirow{3}{*}{ Awareness } & Range & $3-7$ & $8-12$ & $13-17$ & \multirow{3}{*}{14.44} & \multirow{3}{*}{6.39} \\
\hline & & $\mathrm{n}$ & 21 & 92 & 329 & & \\
\hline & & $\%$ & 4.8 & 20.8 & 74.4 & & \\
\hline & \multirow{3}{*}{$\begin{array}{l}\text { Individual and Societal } \\
\text { Readiness }\end{array}$} & Range & $1-2$ & $3-5$ & $6-7$ & & \\
\hline & & $\mathrm{n}$ & 136 & 292 & 14 & 3.70 & 2.94 \\
\hline & & $\%$ & 30.7 & 66.1 & 3.2 & & \\
\hline & & Range & $12-27$ & $28-44$ & $45-60$ & & \\
\hline & Grand Total & $\mathrm{n}$ & 0 & 120 & 322 & 48.61 & 18.51 \\
\hline & & $\%$ & 0 & 27.1 & 72.9 & & \\
\hline & & Range & $5-11$ & $12-18$ & $19-26$ & & \\
\hline & & $\mathrm{n}$ & 4 & 167 & 271 & 19.81 & 5.97 \\
\hline & Geographic inquiry & $\%$ & 0.9 & 37.8 & 61.3 & & \\
\hline & & Range & $3-7$ & $8-12$ & $13-16$ & & \\
\hline త్ర & Personal Protection Measure & $\mathrm{n}$ & 156 & 231 & 55 & 9.56 & 5.90 \\
\hline w & & $\%$ & 35.3 & 52.3 & 12.4 & & \\
\hline$\stackrel{2}{3}$ & & Range & $3-8$ & $9-13$ & 14-18 & & \\
\hline$\frac{\pi}{0}$ & $\begin{array}{l}\text { Physical and Ideological } \\
\text { Attitudes }\end{array}$ & $\mathrm{n}$ & 26 & 138 & 278 & 14.55 & 5.87 \\
\hline & & $\%$ & 5.9 & 31.2 & 62.9 & & \\
\hline & & Range & $12-27$ & $28-44$ & $45-60$ & & \\
\hline & Grand Total & $\mathrm{n}$ & 0 & 252 & 190 & 43.92 & 17.74 \\
\hline & & $\%$ & 0 & 57 & 43 & & \\
\hline & & Range & $24-75$ & $76-128$ & $129-180$ & & \\
\hline Total & Grand Total & $\mathrm{n}$ & 0 & 132 & 310 & 135.4 & 41.5 \\
\hline & & $\%$ & 0 & 29.9 & 70.1 & & \\
\hline
\end{tabular}


According to Table 3, with regard to the Natural Disaster Knowledge Test, scores between 0 and 20, 21 and 40 and 41 and 60 show low, moderate and high levels, respectively. The ratio of geography students whose scores were in the range of 0-20 and 21-40 were $5.4 \%(n=24)$ and $32.3 \%(n=143)$, respectively. $62.3 \%$ of PGTs $(n=275)$ scored in the range of $41-60$ points. The geography teachers' mean score for the Natural Disasters Knowledge Test was found to be $\bar{X}=42.90$. PGTs' natural disaster knowledge levels are close to high considering that the mean score is within the high score range but has a borderline value. With regard to the sub-dimensions of the knowledge test, pre-service teachers' scores in the distribution of natural disasters, climatological-meteorological disasters and their effects on human beings and geological disasters and their effects on human beings sub-dimensions were at a moderate level whereas those for the natural disaster management and its general qualities sub-dimension were at a high level.

While PGTs' scores in the susceptibility and awareness sub-dimensions of the Affective Dispositions Scale were high, their score range in the individual and societal readiness sub-dimension was found to correspond to moderate levels. The analysis of the results of the scale, in general, showed that while there were no students who got scores in the 12-27 range, 120 pre-service teachers $(27.1 \%)$ got scores in the $28-44$ range, and 322 pre-service teachers $(72.9 \%)$ got scores in the range of 45-60 points. The mean score on the Affective Dispositions Scale was $\bar{X}=48.61$, which indicates a high-level affective disposition based on McBeth et al.'s method. Thus, PGTs' affective dispositions towards natural disasters were high.

While PGTs' scores in the personal protection measures sub-dimension of the behavior scale were at a moderate level, their scores in the geographic inquiry and physical and ideological attitudes subdimensions were just above the borderline value towards the higher end. When the overall results of the study were considered, there were no students who scored in the range of 12-27 points, and $252(57 \%)$ and 190 students (43\%) scored in the range of 28-44 and 45-60, respectively. The mean score that pre-service teachers achieved on the behavior scale was $\bar{X}=43.92$. This mean score suggests that natural disaster behaviors of participants were at a moderate level.

According to the scores of the PGTs indicating their natural disaster literacy levels, there were no participants with a total score within the range of 24-75 points, and $132(29.9 \%)$ and $310(70.1 \%)$ pre-service teachers' scores were in the range of 76-128 points and 129-160 points, respectively. These values suggest that PGTs had scores over the average and prominent levels of natural disaster literacy.

\subsection{Pre-service Geography Teachers' Natural Disaster Literacy Scores according to some Variables}

To find out whether there was a significant difference between pre-service teachers' natural disaster literacy total scores and various variables (i.e. gender, natural disaster course, experiencing natural disasters, immediate family members' experience of natural disasters, participation in natural disaster operations, knowledge of natural disaster organisations and knowledge of campus muster points), t-tests were conducted, and their results are presented in Table 4.

The results presented in Table 4 demonstrate that there was no significant difference between PGTs' natural disaster literacy total scores in terms of gender $\left[t_{(440)}=0.95 ; p>0.05\right]$ and immediate family members' experience of natural disasters $\left[\mathrm{t}_{(440)}=1,90 ; \mathrm{p}>0.05\right]$ variables. In other words, PGTs' natural disaster literacy total scores did not significantly differ based on gender or immediate family members' experience of natural disasters. Natural disaster literacy total scores of participants was significantly different based on taking natural disaster courses $\left[t_{(440)}=4.66 ; p<0.05\right]$ and experience of natural disasters $\left[t_{(440)}=2.33 ; \mathrm{p}<0.05\right]$. The natural disaster literacy total scores of pre-service teachers who took natural disaster courses and those who experienced natural disasters (210.3/ 205.9) were significantly higher than that of others (199.8/ 200.8). Thus, those who took natural disaster courses and those who experienced natural disasters had higher levels of natural disaster literacy. 
Table 4

T-test Results of the Literacy Levels of Geography Teachers in terms of Some Variables

\begin{tabular}{|c|c|c|c|c|c|c|c|}
\hline Variables & Responses & $n$ & $\bar{X}$ & $S D$ & $f$ & $t$ & $p$ \\
\hline \multirow[t]{2}{*}{ Gender } & Male & 271 & 204.2 & 22.08 & \multirow[t]{2}{*}{440} & \multirow[t]{2}{*}{0.95} & \multirow[t]{2}{*}{.340} \\
\hline & Female & 171 & 202.1 & 24.56 & & & \\
\hline \multirow[t]{2}{*}{ Natural Disaster Course** } & Yes & 153 & 210.3 & 21.94 & \multirow[t]{2}{*}{440} & \multirow[t]{2}{*}{4.66} & \multirow[t]{2}{*}{$.000^{*}$} \\
\hline & No & 289 & 199.8 & 22.86 & & & \\
\hline \multirow[t]{2}{*}{ Natural Disaster Experience } & Yes & 229 & 205.9 & 23.69 & \multirow[t]{2}{*}{440} & \multirow[t]{2}{*}{2.33} & \multirow[t]{2}{*}{$.020^{*}$} \\
\hline & No & 213 & 200.8 & 22.10 & & & \\
\hline \multirow{2}{*}{$\begin{array}{l}\text { A Family Member with } \\
\text { Natural Disaster Experience }\end{array}$} & Yes & 253 & 205.2 & 22.99 & \multirow[t]{2}{*}{440} & \multirow[t]{2}{*}{1.90} & \multirow[t]{2}{*}{.057} \\
\hline & No & 189 & 201.0 & 23.01 & & & \\
\hline \multirow{2}{*}{$\begin{array}{l}\text { Participation in Natural } \\
\text { Disaster Operations }\end{array}$} & Yes & 168 & 207.1 & 22.20 & \multirow[t]{2}{*}{440} & \multirow[t]{2}{*}{2.64} & \multirow[t]{2}{*}{$.008^{*}$} \\
\hline & No & 274 & 201.1 & 23.34 & & & \\
\hline \multirow{2}{*}{$\begin{array}{l}\text { Knowledge of Natural } \\
\text { Disaster Organisations }\end{array}$} & Yes & 308 & 207.7 & 21.65 & \multirow[t]{2}{*}{440} & \multirow[t]{2}{*}{6.24} & \multirow[t]{2}{*}{$.000^{*}$} \\
\hline & No & 134 & 193.4 & 23.22 & & & \\
\hline \multirow[t]{2}{*}{ Muster Point in the Campus } & Yes & 107 & 209.0 & 21.25 & \multirow[t]{2}{*}{440} & \multirow[t]{2}{*}{2.91} & \multirow[t]{2}{*}{$.004^{*}$} \\
\hline & No & 335 & 201.6 & 23.37 & & & \\
\hline
\end{tabular}

${ }^{*} \mathrm{p}<0.05$; ${ }^{* *}$ The students were asked if they had taken a course under the name of natural disaster. Some universities offer disasters as an elective course.

Similarly, there was a significant difference between PGTs' natural disaster literacy total scores presented in Table 4 in terms of participation in natural disaster operations $\left[t_{(440)}=2.64 ; \mathrm{p}<0.05\right]$, knowledge of natural disaster organisations $\left[\mathrm{t}_{(440)}=2.91 ; \mathrm{p}<0.05\right]$ and knowledge of campus muster points $\left[t_{(440)}=2.91 ; \mathrm{p}<0.05\right]$. In other words, PGTs' participation in natural disaster activities and their knowledge of natural disaster organisations and campus muster points caused a significant difference in their total natural disaster literacy scores. Furthermore, PGTs who took part in natural disaster activities and knew about natural disaster organisations and campus muster points (207.1/ 207.7/ 209.0) had significantly higher natural disaster literacy total scores than others (201.1/ 193.4/ 201.6).

ANOVA tests were conducted to understand whether PGTs' natural disaster literacy total scores caused a significant difference in terms of the various variables (i.e., university, grade point average, mothers' educational backgrounds, fathers' educational backgrounds and monthly income levels). The results of the ANOVA tests are presented in Table 5.

Pre-service geography teachers' natural disaster literacy total scores significantly differed based on the university attended by them $\left[\mathrm{F}_{(3,438)}=12,15 ; \mathrm{p}<0.05\right]$. According to Scheffe test results, natural disaster literacy total scores of students studying geography at Ardahan University $(\bar{X}=194.4)$ were significantly lower than those of the students at Kastamonu University $(\bar{X}=202.5)$, Akdeniz University $(\bar{X}=210.2)$, and Gazi University $(\bar{X}=209.3)$. Furthermore, the total scores of students studying at Akdeniz University $(\bar{X}=210.2)$ were significantly higher than that of those studying at Kastamonu University $(\bar{X}=202.5)$.

The grade point average (GPA) variable was also found to create a significant difference with respect to PGTs' natural disaster literacy total scores $\left[\mathrm{F}_{(4,437)}=4,00 ; \mathrm{p}<0.05\right]$. Tamhane's $\mathrm{T} 2$ test was conducted to identify the direction of the significance. Test results indicate that pre-service teachers having a GPA between 1.50 and 2.49 had significantly lower natural disaster literacy total scores $(\bar{X}=199.5)$ than those whose GPA was in the ranges of $2.50-2.99(\bar{X}=207.2)$ and 3.50-4.00 $(\bar{X}=207.3)$. Thus, there is a positive correlation between students' GPA and natural disaster literacy levels. 
Table 5

One Way Analysis of Variance Results of PGTs' Mean Disaster Literacy Scores According to Various Variables

\begin{tabular}{|c|c|c|c|c|c|c|c|}
\hline Variables & Responses & $n$ & $\bar{X}$ & $S D$ & $F$ & $p$ & $\begin{array}{l}\text { Significant } \\
\text { Difference }\end{array}$ \\
\hline \multirow{4}{*}{ Grade Level } & 1) Grade 1 & 114 & 198.5 & 24.52 & \multirow{4}{*}{6.27} & \multirow{4}{*}{$.000^{*}$} & \\
\hline & 2) Grade 2 & 123 & 199.7 & 23.30 & & & $1-3$ \\
\hline & 3) Grade 3 & 89 & 209.1 & 20.65 & & & $2-3$ \\
\hline & 4) Grade 4 & 116 & 207.9 & 21.53 & & & \\
\hline \multirow{4}{*}{ University } & 1. Kastamonu & 133 & 202.5 & 23.40 & \multirow{4}{*}{12.15} & \multirow{4}{*}{$.000^{*}$} & $1-2$ \\
\hline & 2. Ardahan & 122 & 194.4 & 23.68 & & & $1-3$ \\
\hline & 3. Akdeniz & 141 & 210.2 & 21.61 & & & $2-3$ \\
\hline & 4. Gazi & 46 & 209.3 & 15.74 & & & $2-4$ \\
\hline \multirow{4}{*}{ Grade Point Average } & $1.1 .50-2.49$ & 215 & 199.5 & 23.8 & \multirow{4}{*}{4.00} & \multirow{4}{*}{$.008^{*}$} & \multirow{4}{*}{$\begin{array}{l}1-2 \\
1-4\end{array}$} \\
\hline & 2. $2.50-2.99$ & 163 & 207.2 & 22.0 & & & \\
\hline & 3. $3.00-3.49$ & 52 & 206.5 & 21.6 & & & \\
\hline & 4. $3.50-4.00$ & 12 & 207.3 & 20.0 & & & \\
\hline \multirow{4}{*}{$\begin{array}{l}\text { Mother's Educational } \\
\text { Background }\end{array}$} & 1. Illiterate & 101 & 197.6 & 23.1 & \multirow{4}{*}{3.88} & \multirow{4}{*}{$.009^{*}$} & \\
\hline & 2.Primary School & 265 & 205.8 & 21.8 & & & \\
\hline & 3. High School & 56 & 205.1 & 25.0 & & & \\
\hline & $\begin{array}{l}\text { 4.Undergraduate- } \\
\text { Graduate Degree }\end{array}$ & 20 & 196.2 & 28.1 & & & $1-2$ \\
\hline \multirow{4}{*}{$\begin{array}{l}\text { Father's Educational } \\
\text { Background }\end{array}$} & 1. Illiterate & 38 & 197.0 & 27.1 & \multirow{4}{*}{2.07} & \multirow{4}{*}{.103} & \\
\hline & 2. Primary School & 288 & 204.9 & 22.2 & & & \\
\hline & 3. High School & 89 & 200.4 & 22.1 & & & \\
\hline & $\begin{array}{l}\text { 4.Undergraduate- } \\
\text { Graduate Degree }\end{array}$ & 27 & 206.7 & 26.5 & & & - \\
\hline \multirow{4}{*}{ Monthly Income } & 1. 0-1500 TL & 189 & 200.2 & 23.37 & \multirow{4}{*}{2.65} & \multirow{4}{*}{.053} & \multirow[b]{4}{*}{ - } \\
\hline & 2. $1500-3000 \mathrm{TL}$ & 160 & 206.0 & 22.40 & & & \\
\hline & 3. $3000-4500 \mathrm{TL}$ & 59 & 207.6 & 20.62 & & & \\
\hline & 4. Above $4500 \mathrm{TL}$ & 34 & 201.3 & 26.59 & & & \\
\hline
\end{tabular}

${ }^{*} \mathrm{p}<0.05$

Table 5 shows that their mothers' educational background led to a significant difference in PGTs' natural disaster literacy total scores $\left[\mathrm{F}_{(3,438)}=3,88 ; \mathrm{p}<0.05\right]$. The Scheffe test results show that the natural disaster literacy total scores of pre-service teachers whose mothers were primary school graduates $(\bar{X}=205.8)$ were high enough to create a significant difference when compared to the scores of participants whose mothers were illiterate $(\bar{X}=197.6)$.

Grade level, the university attended, GPA and mothers' educational backgrounds had a significant impact on natural disaster literacy. However, PGTs' natural disaster literacy total scores did not differ significantly in terms of their father's educational background $\left[\mathrm{F}_{(3,438)}=2,07 ; \mathrm{p}>0.05\right]$ or monthly family income $\left[\mathrm{F}_{(3,438)}=2,65 ; \mathrm{p}>0.05\right]$ variables. In other words, fathers' educational background and monthly family income did not create a significant difference in natural disaster literacy total scores.

\section{Discussion}

In this part of the study, the findings obtained from the problems and sub-problems were interpreted, discussed in the context of the studies related to the research, and inferences were made in line with the findings.

The affective dispositions of PGTs toward natural disasters were shown to be strong in this study. Participants scored higher in the susceptibility and awareness sub-dimensions of the 
Affective Dispositions Scale and scored moderately in the individual and societal readiness subdimension. In the study conducted by Wang et al. (2012), it was identified that participants' attitudes towards disaster prevention were positive; in their study, conducted with school administrators and teachers, Chung and Yen (2016) determined that participants' attitudes towards disaster prevention were high. When compared with the results of similar studies conducted to determine geography teachers' natural disaster literacy levels, participants' attitude towards natural disasters was positive. Having a positive attitude towards an event or phenomenon or having a high level of attitude will have a direct impact of the achievement.

Based on the mean score on the Natural Disasters Related Behaviors Scale, it can be argued that the behaviors of PGTs concerning natural disasters were at moderate level. The behavior dimension representing the internalisation of knowledge and its transformation into action is one of the components of natural disaster literacy. The moderate results for the behavior component show that there are flaws in processes connected to internalizing and translating information about natural disasters into behavior The disaster prevention skills of high school teachers were found to be lacking in a study done by Wang et al. (2012). Similarly, Priyowidodo and Luik (2013) discovered that the public's tsunami-related behavior was insufficient in their investigation. However, in a research of school administrators and teachers done by Chung and Yen (2016), it was discovered that their disaster prevention skills were excellent. Based on these findings, it is possible to conclude that natural disaster-related behavior levels change among countries due to variances in disaster education systems.

When the scores of PGTs for natural disaster literacy levels were examined, it was observed that nearly two-thirds of the teachers who participated in the study were in the high. The high degree of natural disaster literacy is assumed to be due to factors such as completing classes on naturehuman interaction during their undergraduate education and their commitment to respect and protect nature. On the other hand, it was found that participants' natural disaster literacy total scores did not significantly differ in terms of gender or immediate family members' experiences of natural disaster variables. These results, albeit not causally related to natural disaster literacy, are parallel with the findings of Karakuş and Önger (2017), Uzunyol (2013), and Chung and Yen (2016). A difference based on gender was seen in the study conducted by Cvetkovic and Stanisic (2015), wherein it was found that female students were more successful.

Natural disaster literacy total scores of PGTs differed significantly depending on whether or not they had completed natural disaster-related courses in their undergraduate programs or had prior experience with natural disasters. This demonstrates that completing natural disaster courses as part of an undergraduate geography degree improves natural disaster literacy. These findings appear to be consistent with those of Goddard (2017) and Cvetkovic and Stanisic (2015). The results of the current study revealed that pre-service teachers' behavior and attitudes were significantly different whether they had previously experienced natural disasters. This result is in line with the findings in Uzunyol's study (2013). Similarly, in their study, Chung and Yen (2016) found that teachers and school administrators having previous experience of natural disasters had higher levels of disaster prevention knowledge, attitudes and skills compared to those who had not experienced natural disasters before.

Another result was that the total scores of participants' natural disaster literacy differed significantly from the variables of participation in natural disaster operations, knowledge of natural disaster organizations, and awareness of campus muster stations. The participation in natural disaster-related events, recognition of institutions, and knowledge of emergency meeting sites show that they are aware of natural disasters and have a high level of susceptibility. The fact that the overall scores of natural disaster literacy differ significantly proves this result. In studies conducted by Aydn (2010) and Aksoy (2013), it was discovered that factors such as having lived through an earthquake, the seismicity of the region of residence, and the environment inhabited had an impact on earthquake knowledge, awareness, and behavior. 
Natural disaster literacy total scores among PGTs differed significantly by grade level. Students in their third and fourth years of study had higher total natural disaster literacy ratings than those in their first and second years of study. Thus, diversifying undergraduate courses to include more than just natural disaster courses (e.g., transferring themes into other natural disaster courses) would have a direct impact on natural disaster literacy. According to the findings, 3rd and 4th year students have higher scores, and undergraduate education teachings contribute to natural disaster literacy. In the study conducted by Tekin and Dikmenli (2021), it is conlcuded that the attitudes and knowledge levels of the faculty members who teach the course about natural disasters are effective on the interest of teacher candidates in natural disasters. It should be noted that these courses are of critical importance for teacher candidates to be successful in the course they take on natural disasters and to increase their knowledge about natural disasters.

Natural disaster literacy total scores of PGTs ranged significantly depending on which university they attended. Pre-service teachers who studied at the Akdeniz and Gazi universities had higher total scores in comparison to the students of other universities. The lowest mean total score belonged to the students attending Ardahan University. This could be because Ardahan University's university exam placement scores for its programs were lower than those of other universities. In terms of monthly family income levels and the fathers' educational background characteristics, participants' total natural disaster literacy scores did not differ significantly. According to Sözcü and Aydnözü (2019), teacher candidates' natural disaster literacy levels differ significantly from their university and academic averages.

Another variable causing a significant difference in participants' natural disaster literacy total scores was their GPA. The higher the PGTs' GPA was, the higher their natural disaster literacy total scores were. Another variable in which participants' scores showed a significant difference was that of their mothers' educational background. Pre-service teachers whose mothers were primary school graduates had higher scores compared to those whose mothers were illiterate. This result indicates the impact that mothers have on their children's education and underlines the importance of mothers' level of education explicitly. When the natural disaster literacy total scores were analyzed in terms of participants' mothers' educational background, a significant difference was found between PGTs' scores on the Natural Disaster Knowledge Test. Similar to this result, in their studies conducted with secondary school students Karakuş and Önger (2017), Uzunyol (2013) and Cvetkovic and Stanisic (2015) found that the higher the participants' mothers' education levels were, the more the students' natural disaster knowledge levels increased.

In terms of grade level, natural disasters in the subjects of participating in natural disasters and activities related to natural disasters at the university, taking lessons, natural disasters, natural disasters, life, academic GPA and maternal education level, literacy, making a difference; There was no significant difference in terms of gender, natural disaster, surviving first degree relative, monthly income and education level of the father.

The results showed that there was an increase of knowledge and understanding of students by $91.6 \%$ through geographic literacy given in student learning on the material of disaster-related theme. Therefore, teachers are expected to use teaching materials based on geographical perspective to support learning of disaster risk reduction. So that students have good disaster response skills and find the solution for natural damage and reduce its negative side effects (Kamil et al., 2020). For this reason, it is of great importance that the disaster literacy levels of geography teacher candidates are high.

\section{Conclusion and Suggestions}

In this study, natural disaster literacy levels of PGTs were determined according to various variables. Natural disaster literacy has dimensions of knowledge, affective disposition and behavior. It was observed that the PGTs who participated in the study had close to high levels of knowledge of natural disasters. The analysis of their scores on the sub-dimensions of the knowledge test showed that PGTs' scores in the distribution of natural disasters, climatological 
and meteorological disasters and their effects on human beings and geological disasters and their effects on human beings were at a moderate level; their scores in the natural disaster management and its general qualities sub-dimension were at a high level. What is remarkable about these results is that the PGTs do not have a high level of knowledge about the impact of disasters on humans. As geography is a branch of science that feeds on the interaction of nature and human beings, it is expected that future geography teachers will be better equipped in this regard. It can be said that the education provided in the emergence of this situation is more effective to remain in the theoretical framework.

According to McBeth et al. (2008), the participants can be classed as having moderate to high levels of natural disaster literacy. Natural disaster literacy levels of PGTs who will play a major role in building a literate society can be considered as an advantage for the society in the future years where natural disasters are predicted to occur. PGTs' natural disaster literacy levels vary according to the university where they study. It was concluded that the natural disaster literacy levels of PGTs' in the 3rd and 4th grades were higher than the 1st and 2nd grades.

The level of natural disaster literacy was found to be high among PGTs who had taken natural disaster courses in their undergraduate education, participated in natural disaster activities, knew the name of the institution related to natural disasters, knew the campus emergency meeting place, and had experienced natural disasters. Natural disaster literacy levels were also shown to be high among individuals with strong academic scores and high maternal education levels.

Based on the results presented above, the following recommendations are proposed:

1- All teacher education programmes, regardless of the subject matter, should include courses on natural disaster literacy because teachers must have natural disaster literacy to be able to contribute to natural disaster literacy in society.

2-In order for countries to be protected from disasters before natural disasters, to know how to behave during natural disasters, and then to normalize life in the fastest way and to overcome this situation with minimum harm, a serious disaster education should be given in pre-school and primary education period starting from family.

3- Rather than including natural disaster topics in a fragmented fashion within the curriculum of various subjects, including an independent course on this topic as part of secondary or high school education should be considered as pertinent to be able to reach a society with a high level of natural disaster literacy. In addition to this idea, Zhu and Zang (2017) recommend that schools construct disaster-related curricula, integrate disaster education curricula among mandated curricula, and build special disaster textbooks.

4- In order for the future geography teachers to have a higher level of behavior for natural disasters, it will be useful to increase the opportunities to participate in the educations on natural disasters.

\section{References}

Ahmed, M. (2011). Defining and measuring literacy: Facing the reality. International Review of Education, 57(12), 179-195. https://doi.org/10.1007/s11159-011-9188-x

Aksoy, B. (2013). Qualitative survey of perception of 9th graders who experienced an earthquake towards the concept "Earthquake". Zeitschrift für die Welt der Türken Journal of World of Turks, 5(1), 247-265.

ALEA (2015). Literacy in 21st century Australia: the ALEA Declaration. https://www.alea.edu.au/aboutus/alea-literacy-declaration

Aydin, F. (2010). THE perceptions of primary education eighth grade students towards "earthquake": a phenomenographic analysis. Turkish Studies International Periodical for the Languages, Literature and History of Turkish or Turkic, 5(3), 801-817.

Boon, H. J. \& Pagliano, P. J. (2014). Disaster education in Australian schools. Australian Journal of Environmental Education, 30(2), 187-197. https:// doi.org/10.1017/aee.2015.8

Browm, L., Haun, L. \& Peterson, L. (2014). A proposed disaster literacy model, Disaster Medicine and Public Health Preparedness, 8(3), 267-275. https://doi.org/10.1017/dmp.2014.43 
Chung, S.-C. \& Yen, C.-J. (2016). Disaster prevention literacy among school administrators and teachers: A study on the plan for disaster prevention and campus network deployment and experiment in Taiwan. Journal of Life Sciences, 10, 203-214. https:/ / doi.org/10.17265/1934-7391/2016.04.006

Cvetković, V. M. ve Stanisic, J. (2015). Relationshıp between demographic and environmental factors and knowledge of secondary school students on natural disasters. Journal of the Geographical Institute'Jovan Cvijic'SASA, 65(3), 323-340.

CRED. (2015). The human cost of natural disasters a global perspective. http://cred.be/sites/default/files/The_Human_Cost_of_Natural_Disasters_CRED.pdf

Disaster and Emergency Management Presidency [DEMP] (2018). Türkiye'de afet yönetimi ve doğa kaynaklı afet istatistikleri [Disaster management and natural disaster statistics in Turkey]. https://www.afad.gov.tr/kurumlar/afad.gov.tr/35429/xfiles/Turkiye_de_Afetler.pdf

Ergünay, O. (2007, December 5-7). Türkiye'nin afet profili [Turkey's disaster profile]. Paper presented at TMMOB Disaster Symposium. Ankara.

Fothergill, A. \& Peek, A. (2004). Poverty and disasters in the United States - a review of recent sociological findings. Natural Hazards, 32, 89-110. https:/ / doi.org/10.1023/B:NHAZ.0000026792.76181.d9

Field, A. (2009). Discovering statistics using SPSS (3rd edition). London: Sage Publications.

Goddard, S. (2017). Disaster preparedness knowledge, beliefs, risk-perceptions, and mitigating factors of disaster preparedness behaviors of undergraduate students at a LargeMidwest University (Doctoraldissertation), AT Still University of Health Sciences.

Kamil, P.A., Utaya, S., Sumarmi \& Utomo, D.H. (2020). Improving disaster knowledge with in high school students through geographic literacy. International Journal of Disaster Risk Reduction, 43, 101411. https://doi.org/10.1016/j.ijdrr.2019.101411

Karakuş, U. ve Önger, S. (2017). The understanding levels on natural disasters and disasters education concepts for 8th grade students. Journal of History Culture and Art Research, 6(6), $482-491$. http:/ / doi.org/10.7596/taksad.v6i6.1247

Karasar, N. (2012). Bilimsel araştırma yöntemleri [Scientific research methods]. Nobel.

Knobel, M. \& Lankshear, C. (2007). A new literacies sampler. Peter Lang.

McBeth, W., Hungerford, H., Marcinkowski, T., Volk, T. \& Meyers, R. (2008). National environmental literacy assessment project: Year 1, National baseline study of middle grade students; final research report. Unpublished Project Report. Florida Institute of Technology, Melbourne, USA.

Montz, B. E., Tobin, G. A. \& Hagelman III, R. R. (2017). Natural hazards: explanation and integration. Guilford Press.

Özey, R. (2011). Afetler coğrafyası [Disaster Geography] (2nd press). Aktif.

Patton, M. Q. (2002). Qualitative evaluation and research methods. USA: Sage.

Priyowidodo, G. \& Luik, J. E. (2013). Communicating disaster mitigation literacy to coastal communities in Pacitan Indonesia (Doctoral dissertation). http:/ / repository.petra.ac.id/16596

Rahim, N. B. A. \& Wu, B. S. (2015). Disaster prevention literacies: assessing the knowledge, skills and attitude of Taiwanese students for an earthquake disaster. HSSE Online, 4(1), 30-40.

Robson, C. (2002). Real world research: A resource for social scientists and practitioner-researchers. WileyBlackwell.

Hewitt, K. \& Sheehan, L. (1969). A pilot survey of global natural disasters of the past twenty years. Working Paper \#11. Boulder, CO: Natural Hazards Center, University of Colorado.

Sampurno, P. J., Sari, Y. A., \& Wijaya, A. D. (2015). Integrating STEM (Science, Technology, Engineering, Mathematics) and Disaster (STEM-D) education for building students' disaster literacy. International Journal of Learning and Teaching, 1(1), 73-76.

Sözcü, U. (2019a). Determining natural disaster literacy levels of preservice teachers (Unpublished doctoral dissertation). Kastamonu University.

Sözcü, U. (2019b). Doğal afetler ve doğal afet okuryazarlı̆̆ı [Natural disasters and natural disaster literacy]. Pegem Akademi.

Sözcü, U. \& Aydınözü, D. (2019). Examining the natural disaster literacy levels of pre-service teachers according to some variables. International Journal of Geography and Geography Education (IGGE), 40, 79-91. https:// doi.org/10.32003/iggei.566164

Tekin, Ö. \& Dikmenli, Y. (2021). Analysis of pre-service classroom teachers' disaster awareness perception and earthquake knowledge level. Ahi Evran Üniversitesi Journal of the Institute of Social Sciences, 7(1), 258271. https:/ / doi.org/10.31592/aeusbed.811043 
Uzunyol, B. (2013). Measuring the level of the eight-grade students about naturel disasters with respect to several variables (Unpublished Master's Thesis). Niğde University.

UNESCO. (2006). Understandings of literacy. http://unesco.org/education/GMR2006/full/chapt6_eng.pd

United Nations Office for Disaster Risk Reduction [UNISDR-CRED] (2016). Tsunami disaster risk, past impacts and projections. https://www.unisdr.org/we/inform/publications/50825

Varol, N. (2007, December 5-7). Doğal ve teknolojik afetler konusunda toplumun bilinçlendirilmesi ve 'AFEM' in rolü [Society in natural and technological disasters raising awareness and the role of "AFEM"]. Paper presented at TMMOB Disaster Symposium. Ankara.

Wang, M., We1, D. Y., Zhu, X. L., \& Yl, N. (2012). An investigation on disaster prevention literacy of secondary school teachers in China. Journal of Educational Studies, 5, 12.

Yıldırım, A. \& Şimşek, H. (2013). Nitel araştırma yöntemleri [Qualitative research methods] (9th press). Ankara: Seçkin.

Zhu, T.T. \& Zhang, Y.Y. (2017). An investigation of disaster education in elementary and secondary schools: evidence from China. Nat Hazards, 89, 1009-1029. https:/ / doi.org/10.1007/s11069-017-3004-2 